\title{
Empowerment Efforts in Minimizing Community Conflict in the Forest Zone (Study in the Lumajang Regency Forest)
}

\author{
Gading Gamaputra ${ }^{1}$, Mahendra Wardhana ${ }^{2}$, Hezron Sabar Rotua Tinambunan ${ }^{3}$, Noviyanti ${ }^{4}$, \\ Prasetyo Sibandono ${ }^{5}$, Agus Prasetyawan ${ }^{6}$, Dian Arlupi Utami ${ }^{7}$, Yuni Lestari ${ }^{8}$, Weni Rosdiana ${ }^{9}$ \\ \{gadinggamaputra@unesa.ac.id ${ }^{1}$ \} \\ 1,2,3,4,5,6,7,8.9 Universitas Negeri Surabaya, Indonesia
}

\begin{abstract}
Implementation problem of government is policy forest management in Lumajang Regency. Management policy forest conflict is indicative of the many shortcomings that must be corrected. Lumajang Regency, which has self-proclaimed as part of the rule of law and upholds democracy, must act on problems that have dragged on and still occur in various regions. Today's challenge is the preparation of new rules to prevent forest conflict. The need for community empowerment is to take integrated participation by considering sociocultural and macroeconomic values. The research is qualitative research using primary data sources and secondary data. The research locations in several areas of Lumajang regency which included several forest areas were determined purposively. Primary and secondary data are collected through interactive and noninteractive methods. The data obtained were analyzed using interactive analysis and indepth analysis.Problems faced by community in territorial area of the forest area in Lumajang Regency are varied, namely the conflict between the community and the Perhutani (Indonesian state forest company). Community conflicts with Perhutani are the interests of forest people who live with forests managed by BUMN, including the shifting of stake, destruction of cultivation crops, and profit sharing interests in empowering forest communities with Perhutani (Indonesian state forest company).
\end{abstract}

Keywords: Forest Policy, Management, Community Conflict

\section{Introduction}

The mandate of the 1945 Constitution of the Republic of Indonesia in Article 33 paragraph (3) which states that the earth and water and natural resources contained therein are controlled by the state and used for the greatest prosperity of the people, one of which is forests. Forestry management in Indonesian laws and regulations often mismatches with one another, both at the centeral government level and at the local government level [2].

One of the forest conflicts is caused by the government regulation in determining forest areas in Law No. 41 of 1999 [3] concerning Forestry which raises polemics with local governments that refer to local government laws such as Law No. 22 of 1999 [4], Law No. 32 of 2004 [5] and Law No. 23 year 2014 [6]. Polemic occurs because of the delegation of power from the center to the regions in managing their own regions. In article 1 Figures 4 and 5 of Law Number 41 of 1999 concerning Forestry (hereinafter referred to as the Forestry Law) states that there are two forest statuses which are divided into state forest and rights forest [3]. State forests are forests that are located on land that is not burdened with land rights. In contrast, rights forests are forests that are on land that is burdened with land rights. State forest is a forest on which there is no land rights. The authority to administer, utilize, including 
giving permits to third parties in the management of state forests is owned by the Ministry of Forestry [7]. If referring to P. 49 / Ministry of Forestry / 2011 forest status and function as follows:

Table 1. Status and Function Forest

\begin{tabular}{|c|c|c|c|c|c|}
\hline & \multirow{3}{*}{ Forest Function } & \multicolumn{2}{|c|}{ State Forest } & \multirow[b]{2}{*}{$\begin{array}{l}\text { Rights } \\
\text { Forest }\end{array}$} & \multirow{2}{*}{$\begin{array}{c}\text { State Forest } \\
\text { and } \\
\text { Customary } \\
\text { Forest }\end{array}$} \\
\hline & & $\begin{array}{l}\text { Not } \\
\text { Customary } \\
\text { Forrest }\end{array}$ & $\begin{array}{l}\text { Customary } \\
\text { Forest }\end{array}$ & & \\
\hline & & (million ha) & (million ha) & (million ha) & (million ha) \\
\hline 1. & Conservation Forest & 26,82 & Available & Available & 26,82 \\
\hline 2. & Protected Forest & 28,86 & Available & Available & 27,67 \\
\hline \multirow[t]{3}{*}{3.} & Production Forest & 57,06 & Available & Available & 57,84 \\
\hline & $\begin{array}{l}\text { a. Limited Production } \\
\text { Forest }\end{array}$ & 24,46 & Available & Available & 19,68 \\
\hline & $\begin{array}{l}\text { b. Fixed Production } \\
\text { Forest }\end{array}$ & 32,60 & Available & Available & 38,16 \\
\hline 4. & $\begin{array}{l}\text { Conversion Production } \\
\text { Forest }\end{array}$ & 17,94 & Available & Available & \\
\hline 5. & $\begin{array}{l}\text { Extensive Change of the } \\
\text { State Forest Area }\end{array}$ & 130,68 & - & - & 112,33 \\
\hline 6. & $\begin{array}{l}\text { Predetermined State } \\
\text { Forest (million ha) }\end{array}$ & $\begin{array}{l}14,24 \\
(10,9 \%)\end{array}$ & $\begin{array}{l}\text { Fixed } \\
\text { Customary } \\
\text { Forest Not } \\
\text { Programmed }\end{array}$ & - & $\begin{array}{l}\text { Allocation for } \\
\text { Non-Forestry } \\
18,35 \text { million } \\
\text { ha }\end{array}$ \\
\hline 7. & $\begin{array}{l}\text { Current Condition and } \\
\text { Future Estimation }\end{array}$ & $\begin{array}{l}\text { Current } \\
\text { condition is } \\
\text { implication } \\
\text { appointment } \\
\text { = fixed forest } \\
\text { area } \\
\text { (canceled, } \\
\text { Putusan MK } \\
\text { No.45/PUU } \\
\text { IX/2012) }\end{array}$ & $\begin{array}{l}\text { Customary/local } \\
\text { society current } \\
\text { condition are } \\
\text { freely compete } \\
\text { with large } \\
\text { companies }\end{array}$ & $\begin{array}{l}\text { Rights forest } \\
\text { evolve (with } \\
\text { rights } \\
\text { certainty): } \\
\text { Indonesia } 3,59 \\
\text { million ha ( } \\
\text { table } 3 \text {. } \\
\text { Dirjen } \\
\text { BPDASPS, } \\
\text { 2010) }\end{array}$ & $\begin{array}{l}\text { From } 112,3 \\
\text { million ha, } 5,6 \\
\text { million ha } \\
(2030) \\
\text { allocated for } \\
\text { HTR, HKm, } \\
\text { HD }\end{array}$ \\
\hline
\end{tabular}

Source : P. 49 / Ministry of Forestry / 2011.

Data on 2011 state forest areas covering 14.24 million hectares have been established and 126.44 million hectares have not been established. The area of forest in 2030 will be 112.3 million hectares, 5.6 million hectares $(5 \%)$ of which will be allocated to community plantation forests, community forests and village forests. The allocation of forest functions to be managed between the government and forest communities is deemed necessary to reduce forest conflicts. Forest communities are involved in forest management because the community has lived in the forest for a long time.

If forests are managed by the government and forest communities, the level of damage can be reduced. Forest damage is increasing every year. damage due to lack of good forest management between stakeholders. If the forest is destroyed every year, we will all suffer losses. land, air, conflict, animal and infestor losses. the forest can give us good air every day. the forest provides life for animals. forests provide economic value for all. Forest conditions during the period 2009-2013, forests in Indonesia were also damaged. From the picture below, 
it can be seen that the state of Indonesia's forests in the comparison of forest cover area for more details can be seen below:

Fig. 1. Portrait of the State of Forests in Indonesia in Comparison of Forest Cover Areas 2009-2013

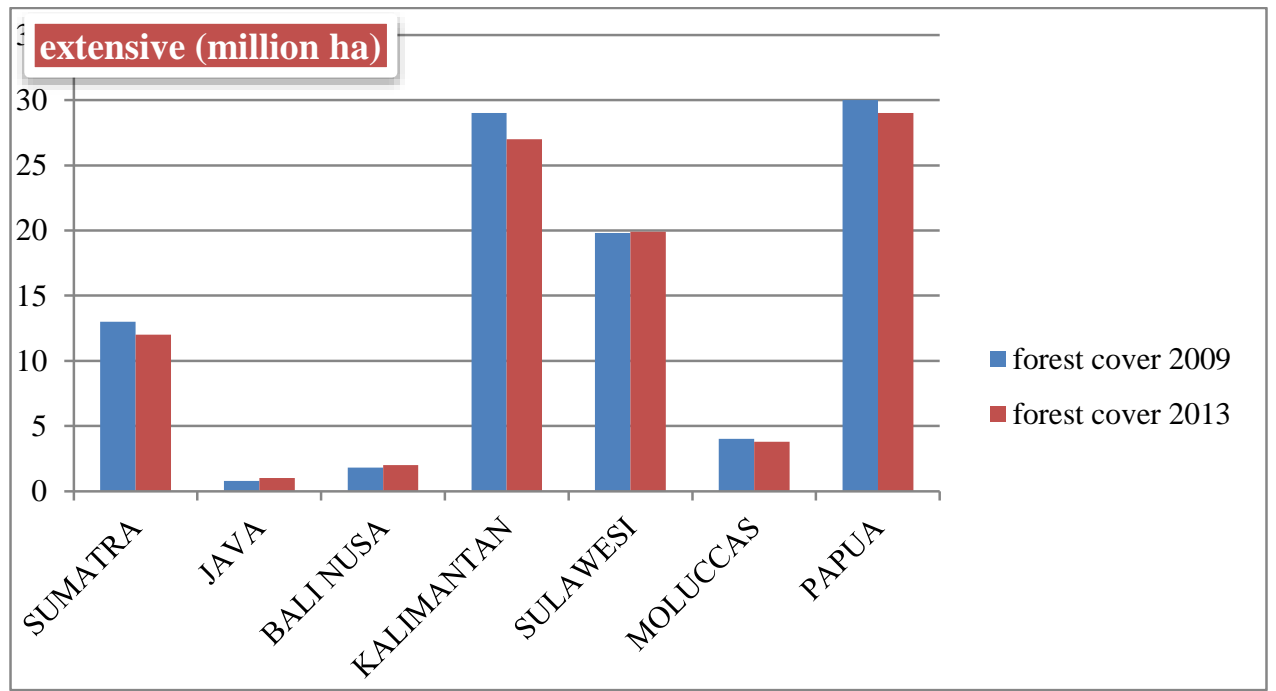

Source : PKHI 2000-2009, Analisis Citra Satelit ETM+7, FWI 2014

Forest utilization by large plantation businesses, mining and transmigration covers 41.01 million Ha or $99.49 \%$ while forest utilization by local / customary communities covers 0.21 million $\mathrm{Ha}$ or $0.51 \%$ of the total forest utilization. This unfair allocation of forest utilization contributes to the occurrence of conflicts and weakening of indigenous and local social capital. Forest management deals with who owns forest land, and who uses, manages and decides on forest resources [8]. The regulatory process as an effort to control (limit) access while at the same time deciding (history) the traditional relations of the population towards agrarian sources which are the main source of livelihood. The territorial strategy is the effort taken by the state to control the lives of the population through surveying and registering land, making maps, establishing and monitoring forest areas and other natural resources [9].

Implementation Government policies unilaterally decide the boundaries of state forest areas with rights forests to cause conflict and differences in views on boundaries (Kornblurn, 2003: 294 [10]). Communities that are not involved in the determination of boundary arrangements end in the relationship between forest resource conflicts between the community and the state is based on monopoly and manipulation of the process of exploitation of forest resources by the state, resulting in debate over access. Different access tends to favor the government and investors who enjoy more results, while the interests of society are neglected [11].

Forestry conflicts also occur in Lumajang Regency. in 2015, thousands of farmers in Lumajang Regency were identified as living in the vicinity of the forest and so far managed the land claimed to be in the Perhutani (Indonesian state forest company) area. This include the districts of Ranuyoso, Klakah, Randuagung, Gucialit, Pasrujambe, Pasirian and Candipuro. Over the last fifteen years, as many as 25 farmers have been in conflict with the law because 
of criminalization. What has been said is from forest clearing, illegal logging, and conflict between groups.

Table 2. Comparison of developments in community forest area in 2012 - 2013 Based on location /

\begin{tabular}{|c|c|c|c|}
\hline \multirow{3}{*}{ No. } & \multirow{3}{*}{ Location } & \multirow{2}{*}{\multicolumn{2}{|c|}{ Quantity (hectare) }} \\
\hline & & & \\
\hline & & 2012 & 2013 \\
\hline 1. & Tempusari & $1.880,33$ & $1.932,83$ \\
\hline 2. & Pronojiwo & $4.890,51$ & $4.940,51$ \\
\hline 3. & Candipuro & $7.186,64$ & $7.211,64$ \\
\hline 4. & Pasirian & $2.816,74$ & $2.836,24$ \\
\hline 5. & Tempeh & $8.852,18$ & $2.852,18$ \\
\hline 6. & Lumajang & 282,53 & 282,53 \\
\hline 7. & Sumbersukko & $1.076,33$ & $1.076,33$ \\
\hline 8. & Tekung & 454,15 & 454,15 \\
\hline 9. & Kinir & $6.333,19$ & $6.333,19$ \\
\hline 10 & Yosowilangun & 317,84 & 317,84 \\
\hline 11. & Rowokangkung & 475,76 & 475,76 \\
\hline 12. & Jatiroto & 141,28 & 141,28 \\
\hline 13. & Randuagung & $1.636,84$ & $1.651,84$ \\
\hline 14. & Sukodono & 143,50 & 143,50 \\
\hline 15. & Padang & $1.730,62$ & $1.730,62$ \\
\hline 16. & Papsrujambe & $2.859,81$ & $2.889,81$ \\
\hline 17. & Senduro & $7.012,58$ & $7.042,58$ \\
\hline 18. & Gucialit & $6.270,30$ & $6.270,30$ \\
\hline 19 & Kedungjajang & $1.755,96$ & $1.785,96$ \\
\hline 20. & Klakah & $2.837,08$ & $2.844,58$ \\
\hline 21. & Ranuyoso & $4.058,83$ & $4.096,33$ \\
\hline & TOTAL & $58.013,00$ & $57.310,00$ \\
\hline
\end{tabular}

Source : Lumajang Regency Forestry Office 2013

The conflict in the Lumajang Regency forest area is caused by community conflict with the Perhutani (Indonesian state forest company). The conflict of interest of forest communities that have lived long with forests managed by BUMN. Conflicts of interest occur such as shifting boundaries, destruction of forest plants, distribution of forest products with forest communities, communities asking for forest land to be certified.

People around the forest who make the position of the forest area that has been determined cannot be separated from the shadow of the conflict in the future. but the Law also does not explain in detail about the status of customary forests or community forests that have settled long in state forest areas even before the Republic of Indonesia.

The emergence of problems in the implementation of forest management policies in Lumajang Regency is an indication that there are still many shortcomings that must be corrected. The challenge faced is the preparation of new policies to prevent conflict. An urgent need is to empower the community, take an integrated approach that considers the sociocultural values of forests and macro economic aspects. 


\section{Research Method}

Research on empowerment in minimizing communities conlict in forest zoneis qualitative research. Qualitative research is an approach that uses investigative analysis by collecting data directly and involving people in the reaserch location. Qualitative research is not obtained from the results of statistics or other calculations (Parsons, 2006) (Sugiono 2003 \& 2012). This research is methodological as a "survey-plus", by identifying primary data on the condition of the people who inhabit or settle around the forest area (obtained through in-depth interviews and observation) with Forestry Office, Environment office, Agriculture Service Office, Perhutani Office (Indonesian state forest company) and people living in forest areas in several forest areas in Lumajang Regency. The research also identified a number of policies / programs / activities of the Regional Government, East Java Provincial Government and Lumajang Regency.

\section{Result and Discussion}

\subsection{Policy on Community Conflict in the Territorial Area of the Lumajang Regency Forest Area}

Lumajang regency has made efforts to minimize the conflict in forest. The Lumajang regency Forestry Office has limited authority in law enforcement when forest conflicts occur. The Forestry Service leads more towards persuasive actions, for example initiating the formation of $\mathrm{LMDH}$, mediating the sharing of forest management results with Perhutani (Indonesian state forest company) and being strengthened by agreements that are legalized by a deed or MoU. The Lumajang Regency Forestry Office agency actively initiates and communicates actively with the LMDH. Furthermore, the Forest Office proposes to the relevant parties to describe in detail the agreement in the $\mathrm{MoU}$ in the future to adjust the interests of each party.

The limited authority of the Forestry Service cannot in detail reach those who have the potential to cause conflict. The government often disseminates information to forest communities so that they do not violate the rules that have been set. socialization is increasingly being carried out by involving parties related to the forest.

The Provincial Government is expected to be able to place authority in forest management as an extension of the central government to the autonomous region. East Java Governor Regulation No. 50 of 2013 [14] concerning the Provincial Forestry Plan for 2012-2032, which in his presentation explained that the potential and conditions of forestry in East Java are quite large and must be directed legally in order to realize shared justice in the community. Implementation Governor regulations should reduce conflict among forest people. The governor's regulation regulates the establishment of forest areas for cultivation, community forest areas for protection and community forest areas for cultivation. So far, the implementation of the governor's regulation was very lacking due to the lack of proactive role of the province in it.

\subsection{Issues Faced Against Community Conflict in the Territorial Territory of the Lumajang Regency Forest Area}

We observed observations to identify and identify conflicts that occurred in the forest area of Lumajang Regency. Observations were made by visiting and conducting intensive 
interviews with parties from the Forestry Office, Environment office, Agriculture Service Office, Perhutani Office (Indonesian state forest company) and people living in forest areas in several forest areas in Lumajang Regency. Forestly conflict in Lumajang Regency between custom society and perhutani (Indonesian State Forest Company) as in :

1. Society forest area conflict, either individually nor community that behalf of NGO demanding for distribution of forest land area to owned. Society desire forest land area to be owner right or ownership certificate.

2. Society demand to get forest land often ridden by certain person so that forest conflict become politically. Politician come and offer solution that will help forest society for some vote on elections. But in fact, the forest conflict still unsolved.

3. Society also spend their own money to pay a notary but still not get their rights to forest land.

4. Society conflict with perhutani (Indonesian State Forest Company) also affected by administration stuff. Administration problem which concerns the forest conflict is the appear of SPPT (Tax Payable Notification) from land which owned by forest society, even though the forest society in that conflict area doesn't have rights for the land of their own. A placeman in the involved area untill SPPT (Tax Payable Notification) appeared can be the trigger of requirement rights to the land from that forest society.

5. The society often do illeg logging then planting plants which not the plants for the forest area.

6. The production tree owned by perhutani (Indonesian State Forest Company) precisely became a target from society that don't understand by do revocation of production seeds that owned by perhutani which grows with society's plants.

7. Society afraid to go into perhutani (Indonesian State Forest Company) area causes by criminalized as the cases that happened before that violate the line or ruin the area that not their own.

Goverment limitation for processed the conflict. Limitation authority of the Forest Service which just processed citizen forests makes the local goverment can not act as much to mediate the conflict teterritory forest society especially with ownership rights for the land that crushing with perhutani's. The boundary line between forest which management area of perhutani with that not renewed in every year by BPN (National Land Affair Agency) and Perhutani (Indonesian State Forest Company) can not give the right solution for the conflict. Perhutani (Indonesian State Forest Company) also give the solution for the distribution of forest products $25 \%$ for society, but the society also still insisted owning forest land.

Personally limitation from perhutani's side Limitation of personally became the problem for perhutani side for established the forest regulation as it. Said that in 5000ha there are just 5 to 7 pforest police personnel which maintain production forest areas under Perhutani's control. So that perhutani as it self can not do controling as much if that happen if a violation occurs.

\subsection{Ways to Resolve Conflict in the Lumajang Forest Area}

Community conflicts with the government are not new in forestry. Communities living in the forest area have high interests to forest. The community's demand is to obtain land ownership rights over their working land. The community knows that they are not easy to agree to. UU no. 41 of 1999 clearly distinguishes between production forests, state forests, community forests and rights forests, that although forest communities demand rights that are not in accordance with the rules, they cannot be achieved. 
In a normative jurisdiction, Perhutani (Indonesian State Forest Company) has full authority in managing state forests. Forest management by Perhutani (Indonesian State Forest Company) is regulated in Government Regulation No. 72 of 2010 concerning State Forestry Public Corporation (Perum) [15]. Article 3 of the PP states that forest management activities include governance and plans for management, use, rehabilitation and reclamation, protection and nature conservation forest. The most important thing is existence of Perhutani's authority in the appointment, determination, change of status, to the granting of permission to certain parties to manage the forest owned by Perhutani (Indonesian State Forest Company). The government must form an LMDH to resolve conflicts with the community. LMDH was formed by containing key figures in the forest community. The purpose of establishing LMDH is to obtain the aspirations of the community and negotiate joint forest management. Forest management with community and government. Based on the Decree of the Director of Perhutani No. 682 / KPTS / Dir / 2009 also agreed on the establishment of the LMDH (Village Forest Community) as a solution to open opportunities for working together to manage forest together with the community[16].

\section{Conclusion}

1. Forest Management in Lumajang refers to East Java Governor Regulation No. 50 of 2013 concerning the Provincial Forestry Plan for 2012-2032 as a guideline in matters of forest management which are the authority of the Provincial Government. Forest management carried out includes the implementation of forest governance, plans for managing forest management units, forest use, rehabilitation, forest protection, management of non-timber and timber forest products, and management of KHDTK for religious purposes. In Lumajang, forest management policies are persuasive with the formation of LMDH (Village Forest Community), socialization, and formulation of memoranda of understanding.

2. Conflict issues in Lumajang Regency are related to there is no database and information regarding comprehensive forestry conflicts, there is no institution that specifically has the authority to deal with agrarian conflicts, the process of forest gazettement cannot be a way for conflict resolution, and forest management options are not able to become a bridge to the legality of community rights on forest resources.

3. Conflicts between the community and Perhutani (Indonesian State Forest Company) are more common than community conflicts with investors.

\section{References}

[1] "Undang-Undang Dasar Negara Republik Indonesia 1945."

[2] I. Hakim, S. Irawanti, S. Murniati, A. Widiarti, R. Effendi, M. Muslich, and S. Rulliaty, "Social Forestry Menuju Restorasi Pembangunan Kehutanan Berkelanjutan," Bogor, Indones. Pus. Penelit. dan Pengemb. Perubahan Iklim dan Kebijak., 2010.

[3] "Law Number 41 of 1999 On Forestry."

[4] "Law Number 22 of 1999 On Local Goverment."

[5] "Law Number 32 of 2004 On Local Goverment."

[6] "Law Number 23 Of 2014 On Local goverment."

[7] M. A. Safitri, "Forest Tenure in Indonesia: the socio-legal challenges of securing 
communities' rights." Faculty of Law, Leiden University, 2010.

[8] A. M. Larson, "Hak tenurial dan akses ke hutan: Manual pelatihan untuk penelitian," CIFOR. Bogor, vol. 15, 2013.

[9] D. Gustian, Teritorialisasi dan Perubahan Ruang Penghidupan Rakyat dalam Politik Ruang dan Perlawanan: Kisah Konflik atas Ruang di Tingkat Lokal. Bogor: JKPP, 2014.

[10] N. Susan, Sosiologi konflik \& isu-isu konflik kontemporer. Kencana Prenada Media Group, 2009.

[11] R. Lawang, "Buku Materi Pokok Pengantar Sosiologi," Jakarta Univ. Terbuka, 1994.

[12] P. Wayne, "Public Policy: Pengantar Teori dan Praktik Analisis Kebijakan," Jakarta: Kencana, 2006.

[13] Sugiyono, Metode Penelitian Pendidikan Pendekatan Kuantitatif, Kualitatif, dan R \& $D$. Bandung: Alfabeta, 2009.

[14] "East Java Governor Regulation Number. 50 of 2013 On Provincial Foresrty Plan Year 2012-2032."

[15] "Goverment Regulation Number. 72 of 2010 On Indonesian State Forest Company."

[16] "Letter of Attorney Indonesian State Forest Company Number. 682/KPTS/Dir/2009." 